\title{
Transatlantica
}

Revue d'études américaines. American Studies Journal

\section{Piecing the Broken Golden Bowl: Dislocation and Diplomacy in Nixon in China by John Adams and Alice Goodman}

Mathieu Duplay

\section{OpenEdition}

Journals

Electronic version

URL: https://journals.openedition.org/transatlantica/17139

DOI: 10.4000/transatlantica.17139

ISSN: $1765-2766$

Publisher

Association française d'Etudes Américaines (AFEA)

\section{Electronic reference}

Mathieu Duplay, "Piecing the Broken Golden Bowl: Dislocation and Diplomacy in Nixon in China by John Adams and Alice Goodman", Transatlantica [Online], 1 | 2021, Online since 01 July 2021, connection on 31 January 2023. URL: http://journals.openedition.org/transatlantica/17139 ; DOI: https://doi.org/ 10.4000/transatlantica.17139

This text was automatically generated on 31 January 2023

\section{(c) (†)}

Creative Commons - Attribution-NonCommercial-NoDerivatives 4.0 International - CC BY-NC-ND 4.0 https://creativecommons.org/licenses/by-nc-nd/4.0/ 


\title{
Piecing the Broken Golden Bowl: Dislocation and Diplomacy in Nixon in China by John Adams and Alice Goodman
}

\author{
Mathieu Duplay
}

While the initial idea for Nixon in China, John Adams's first stage work, was suggested by director Peter Sellars (Adams, 2008 127), its final shape owes much to a series of creative decisions whose nature may well surprise those who insist on viewing it as a paradigmatic example of "CNN opera," a deprecatory phrase still in use among its detractors (Tarling 250). According to Adams, the work's complex genesis began when Sellars came up with its "wry and mischievous" title (2008 127)-one that brilliantly encapsulates the tenor of the whole project, despite the misunderstandings to which it has been subjected ever since the 1987 premiere. Misled by Sellars's formulation, many still assume that the opera's primary purpose is mimetic and that it aims at recreating a (relatively) recent event, namely President Richard Nixon's epochal visit to Communist China in February 1972; but a closer look at the subject chosen by Sellars suggests that this is not the case. By the mid-1980s, Mao and Zhou Enlai ${ }^{1}$ were both dead; Jiang Qing was serving a life sentence; Deng Xiaoping's "Four Modernizations" policy was rapidly transforming China into a consumer society; in the absence of political changes capable of solving the regime's legitimacy crisis, the resulting wealth inequality gave rise to tensions which eventually found expression during the Tiananmen Square protests of 1989. Equally momentous transformations had taken place on the American side. In the aftermath of Watergate, Nixon had been forced to resign from office; the last American troops had finally withdrawn from Vietnam in 1975; and Ronald Reagan, a Republican president of a rather different stripe, had taken office in 1981, ushering in an era of deepening East-West polarization. Michael Steinberg pointed out in 1988 that, far from trying to compete with the modern news media, the opera portrayed a vanishing, increasingly alien world whose unique challenges were already hard to recapture: "Now that the People's Republic has become a tourist spot with Holiday Inns and 
Sheratons, we are already in danger of forgetting how utterly and hopelessly remote that country once seemed" (114-115).

To the extent that Nixon in China could be described as a political opera, it was certainly not about current politics; the real focus lay elsewhere, and the central concerns were aesthetic. According to John Adams, Sellars's idea was not to try and bridge the gap between the present moment and a past that was already fading from memory, but to compose "a delicious 'East meets West' study in modern Realpolitik" and in the cultural politics of opera by drawing on Maoist propaganda, Chinese ballet, and "Henry Kissinger's pompous, self-congratulatory account of his White House years” (2008 127). The point was not so much to uncover the truth about the Nixon presidency as to use the story of his visit to China as a parable about the power of theatrical representation; as Peter Sellars told Matthew Daines, "You create images, and music, and words that put the viewer on edge to get the picture after their own fashion. No two people will have the same reaction-that's what's exciting about the piece. It fails to dupe the answers for you: you have to fill out your own questionnaire" (13). The proposed work's curiously old-fashioned title was meant to emphasize Sellars's meta-operatic ambitions, as Adams suggests when he likens it to "a pop-art mangling of Iphigenia in Tauris" (2008 127). He does not specify whether he is thinking of Christoph Willibald Gluck's opera Iphigénie en Tauride (1779) or of Goethe's tragedy Iphigenia auf Tauris (1779-1786); however, both works pursue similar goals as they exemplify a neoclassical aesthetic that treats formal perfection as a vehicle for humanist values. If this was the cultural model that Sellars playfully proposed to "mangle," then it should come as no surprise that the finished product also focuses on the functions of artistic form, a rather different undertaking from the illusionistic rendering of current events that Adams and his collaborators are often believed to have attempted.

3 The immediate question, for them, was one of tone. Gluck's "reform" operas, of which Iphigénie en Tauride is an especially successful example, dramatize the conflict between the desire for an artistic "voice that sounds from the depth of nature and the collective consciousness," and "the cruelty man suffered under the yoke of theocratic societies" at a time when belief in monarchical values was losing ground in favor of "a larger investment in ethical and political virtue." Thus, Gluck's quest "for an elevated language that has been lost" reflects a belief in the innate nobility of the human soul, which struggles to find adequate expression in a political environment where obedience to an authoritarian ruler remains the norm (Fend 293). This is a far cry from the democratic aspirations of Pop Art, which its founder Richard Hamilton famously described in the following terms: "Popular (designed for a mass audience), Transient (short-term solution), Expendable (easily-forgotten), Low Cost, Mass Produced, Young (aimed at youth), Witty, Sexy, Gimmicky, Glamorous, Big Business" (Kaizen 113). If Sellars's aim, as understood by Adams, was to rid the Gluckian model of its associations with the Ancien Régime and to reinvent for the age of mass media a genre initially rooted in the cultural terrain of pre-revolutionary Paris, then the issue of language arose once again, since the eighteenth-century tension between innate virtue and enforced obedience to royal authority no longer obtained. How should an elected president, albeit one prone to abusing his powers, express himself if he is to appear as the latter-day reincarnation of a Gluckian (or a Goethean) protagonist? Adams immediately insisted that the libretto must be written in verse to retain something of the grandeur of neoclassical music drama without losing touch with the American 
vernacular: "[I thought] the artifice of verse might lift the story and its characters, so numbingly familiar to us from the news media, out of the ordinary and onto a more archetypal plane" (2008 135). Sellars thought of Alice Goodman, a young writer and scholar steeped in the Elizabethan and Metaphysical traditions, from Thomas Nashe to George Herbert; she had been one of his classmates at Harvard, and he felt she would be able to meet these complex demands. It was an inspired choice: an unknown quantity at the time, Goodman turned out to be a remarkably gifted dramatist whose extensive knowledge of English literature and keen interest in issues of artistic form made her exceptionally suited to the task. An especially strong feature of Goodman's work as a librettist is her ability to reconcile a sense of her characters' archetypal significance with an awareness of their essential ordinariness, of the all too human flaws and foibles that they share with the man and woman in the street; this is reflected in language that combines a high level of formal sophistication with a love of ordinary American speech ("We'll teach/These motherfuckers how to dance!" Madame Mao exclaims in Act 3 in Nixon in China [Goodman 58]). Goodman withdrew from the operatic scene due to the controversy occasioned by the 1991 premiere of The Death of Klinghoffer, her second collaboration with John Adams, ${ }^{2}$ but her importance as a writer has been increasingly acknowledged in recent years; a clear sign of long overdue recognition came in 2017, when both libretti, along with Goodman's English translation of Die Zauberflöte, were published together in book form. An opera libretto that rewards examination as a stand-alone work of poetry, her script for Nixon in China is a rare achievement, and her recent collaboration with British composer Tarik O'Regan (A Letter of Rights, 2015) is an encouraging sign that there may be more to come.

\section{"The Artifice of Verse": Discursive Complexity and the Resistance of Words to Musical Treatment}

While she shared Adams's commitment to a certain nobility of utterance, Alice Goodman was also eager to experiment freely with versification, not because she was unsure of her commitment to the "artifice of verse," but on the contrary because formal intricacies deepen the reader's (or the listener's) awareness of the text as a carefully assembled artifact. A scholar of Renaissance and seventeenth-century literature, Goodman is obviously attracted to the elaborate verbal patterning typical of Early Modern verse; her libretto is almost entirely composed in iambic tetrameters and frequently sounds reminiscent of Andrew Marvell's poetic dialogues, where this meter predominates:

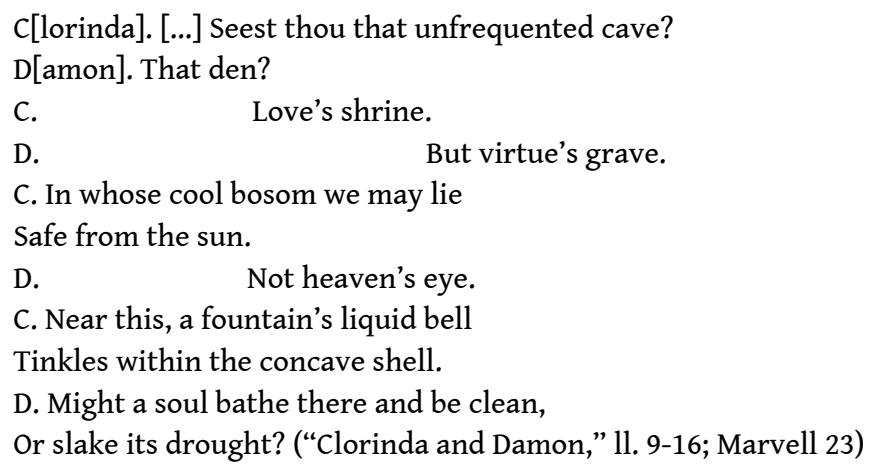


Goodman also appears drawn to twentieth-century Modernist poetry; a former student of Seamus Heaney, who reportedly encouraged her to read David Jones's highly allusive, formally inventive verse (Rahim), she shares Wallace Stevens's penchant for abstraction, and her writings intriguingly recall the intricate, demanding, and deliberately obscure poems of Geoffrey Hill, to whom she was married for thirty years. A literary artist who believes in the resistance of form to ideological pressure and, like Hill, refuses to pander to the contemporary demand for "accessible" writing at the expense of complexity, Goodman is not a postmodern poet, but what Marjorie Perloff calls a "twenty-first century Modernist," one whose interest in verbal artifacts owes much to Gertrude Stein, ${ }^{3}$ William Carlos Williams, and T. S. Eliot. As such, she may be willing to employ traditional meters and adhere to the conventions of verse drama, but she reserves the right to manipulate the libretto's prosody so that the reader/listener is repeatedly faced with unexpected difficulties, as Modernism's oppositional poetics demands.

6 This accounts for Goodman's frequent and bold use of line breaks. In the most general sense, a line break occurs whenever a line of poetry ends and another one begins; complexities may occur when this happens in mid-sentence or in the middle of a clause, giving rise to an enjambment as a syntactical structure is left dangling at the end of one line and is completed in the next. This common procedure often produces striking semantic effects, for instance by creating a sense of suspense or emphasizing words that would not attract the same attention if the text were written in prose. Goodman's use of enjambment is often highly unconventional, and sometimes wildly so; several extreme examples occur, as when Henry Kissinger, Nixon's National Security advisor, compliments Mao on his literary output:

KISSINGER

The Chair-

Man may be gratified to hear

He's read at Harvard. I assign

All four volumes. (12)

7 Here, a compound noun is broken down into smaller units for metrical purposes, deliberately transgressing the rule that line breaks may occur at any point between-but not within-words, at least in the context of a poem that appears to follow seventeenthcentury models: the meter is reminiscent of Marvell, but the enjambment strikingly recalls William Carlos Williams's "red wheel / barrow // glazed with rain / water" (Williams 224). Earlier in the opera, Goodman teasingly leaves a pronoun dangling at the end of a line:

NIXON

We

Stopped in Hawaii for a day

And Guam, to catch up on the time. (6)

8 This would not be remarkable if it were intended to produce a semantic effect, for instance if the character were understood to mean that other members of the American delegation stopped somewhere else or did not stop at all. In context, however, no such comparison is implied; likewise, recalling the etymology of the word "chairman" adds nothing to the audience's understanding of American diplomacy. In Act 1, Scene 3, as Nixon addresses his Chinese hosts at the start of the banquet, he comments on the role of the media: 
[...] No one is out of touch.

Telecommunication has

Broadcast your message into space. (30)

9 Once again, the enjambment serves no clear semantic or expressive purpose; the President is not trying to emphasize the auxiliary "has" to make the point that the broadcast has really taken place (contrary to expectation, or in the face of other people's denials), but is merely stating the obvious. Yet another unconventional use of enjambment occurs at the end of Act 3, when Nixon recalls the hamburger stand he ran on an Army base in the Pacific during the Second World War:

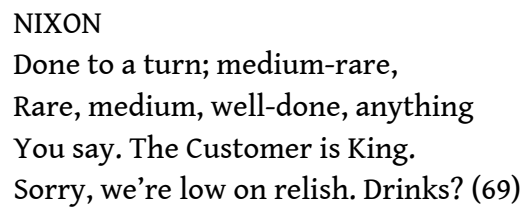

10 As in the other instances listed above, Goodman's handling of versification adds nothing to the meaning, which in any case hardly deserves attention since Nixon is merely stringing together a series of clichés.

11 All these enjambments puzzle the reader because they appear pointless, unlike, for instance, Clorinda's charmingly expressive observation that "a fountain's liquid bell/ Tinkles within the concave shell": the verb "tinkle" would not sound so appealing if it did not stand at the beginning of a line.

Still, unconventional line breaks do perform a clear function throughout Goodman's libretto, where they are treated as markers of discursive complexity. They are virtually absent from the opening chorus, where the soldiers awaiting Nixon's arrival recite Communist slogans:

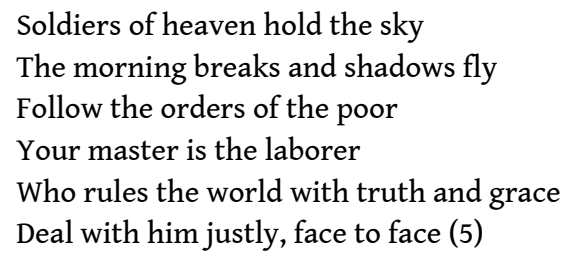

Likewise, very few occur in the scene where Goodman rewrites the scenario of the Red Detachment of Women, the Maoist ballet performed before the American guests:

Young as we are

We expect fear.

Every year

More of us bow

Beneath the shadow

of the next blow. (42)

13 When unusual line breaks are present, they hint at the characters' ability to see through the clichés of conventional wisdom and government propaganda, or else confer a recognizably literary character on otherwise prosaic statements. Kissinger may well be paying the Chinese leader a backhanded compliment since the conservative statesman certainly does not encourage his American students to join the Communist Party: Mao is read at Harvard, but not in the same spirit of indoctrination as in his own country. Nixon's answer to Chou En-lai's question, "Your flight was smooth, I hope?" (6) is rescued from banality by the striking enjambment. The line breaks endow the President's memories of the time he spent flipping burgers with a poetic force they would otherwise lack and emphasize the contrast between the dignity 
of his office and his humble beginnings; as to his commonplace remark about the role of contemporary news media, it serves a meta-poetic purpose since it creatively fits the modern word "telecommunication," with its seven pedantic-sounding syllables, into the short span of an iambic tetrameter. Thus, Goodman remains faithful to the High Modernist agenda: she distances herself from stereotypes, appropriates the latest linguistic fads, and treats the trivialities of everyday chit-chat as raw material on which it is her responsibility to bestow an original, artistically meaningful, and memorable form. Surprising line breaks are especially suited to this purpose: they simultaneously acknowledge and betray the expectations raised by the libretto's adherence to a fixed meter, the better to emphasize the autonomy of poetic language.

In performance, this becomes a source of considerable tension. Line breaks are an essentially literal (as well as literary) device; they are immediately apparent when the text is displayed in written form but become far less noticeable when it is spoken, let alone sung, thus defeating the librettist's-and, perhaps more significantly, the composer's-apparent purpose. What remains of the "artifice of verse" when the text is indistinguishable from prose? In the theater, an actor with a keen sense of prosody may be able to suggest the presence of an enjambment, but this can lead to a dilemma: is it better to pause at the end of each line, even though the result may sound strained ("Chair-/Man") or needlessly insistent ("We/Stopped in Hawaii")? Or should the performer ignore the break and thereby allow the audience to lose all sense of the text's metrical properties? When singing is involved, further difficulties arise. Whenever Adams feels that a line break serves no clear semantic purpose, he sets the text as if it were prose, privileging syntactical continuity at the expense of meter: e.g., Nixon's voice does not pause between "We" and "stopped." In addition, the rich orchestral score is replete with strong rhythmical effects and haunting ostinatos which owe little or nothing to the libretto's prosody and, indeed, tend to draw attention away from the vocal line, as the listener is tempted to focus on instrumental patterns that generally bear no discernible relation to the character's words. This seeming indifference to versification is at odds with the composer's insistence that the use of verse is necessary to "lift the story and its characters [...] out of the ordinary." In the opening scene, the exchange between Nixon and Chou is treated not as a revelatory moment when seemingly trivial words, enunciated with care, carry the weight of history in the making, but as a straightforward bit of recitative leading up to the first major aria, a brilliant solo in which Nixon muses on the power of the media. The difference between the two is unmistakable: the introductory conversation is treated as if the characters spoke in prose and their delivery suggests improvised speech.

There is an important sense, however, in which the question of performance and the listener's inability to perceive line breaks, or recognize them as significant, does not exhaust the issue, let alone render it moot. Music's tendency to draw attention away from the libretto's writerly qualities has traditionally been a complaint of librettists; but in this case the composer's own insistence on setting a formally sophisticated poem instead of a prose text indicates that something unusual is at stake, and that a certain degree of tension between words and music is essential to the project. In addition to revealing the characters' gift for nuanced expression, line breaks draw attention to the gap that separates singing from poetry and suggest the text's resistance to its musical treatment-a resistance no less stubborn for being paradoxical, since Goodman's script was deliberately written with music in mind. Nixon in China thus rejects the Wagnerian 
model of the Gesamtkunstwerk, which seeks to erase the boundaries between musical and verbal modes of expression (Söring 710), in favor of the older tradition of Classical opera, which posits them as irreducibly different. In the age of Mozart, writes Charles Rosen, operatic music did not seek to illustrate every detail of the text; the two unfolded side by side, each deploying its own strategies in pursuit of a common goal.

Mozart [emancipated operatic music] by making [it] not so much an expression of the text [...] but an equivalent for the dramatic action. Mozart's achievement was revolutionary: for the first time on the operatic stage, the music could follow the dramatic movement while still arriving at a form that could justify itself, at least in its essentials, on purely internal grounds. (172-173)

Adams has repeatedly expressed great admiration for Wagner's music dramas, which he credits with having awakened his interest in opera and, more fundamentally, with having alerted him to the expressive power of tonal harmony at a time when he felt under pressure to follow in the footsteps of the Second Viennese School (2008, 100-108). Paradoxically, the score of Nixon in China appears in some ways to revert to an older model of music theater, for instance by reviving the division between recitative and aria (cf. Nixon's “News" aria, Pat Nixon's “This Is Prophetic," or Chiang Ch'ing's secondact monologue) and by interspersing the action with orchestral showpieces that could easily function as stand-alone symphonic movements (the 1985 "Foxtrot for Orchestra" entitled The Chairman Dances has been described by the composer as an "out-take" from Act 3, with which it shares a great deal of thematic material; see Official Composer Website). This throwback to eighteenth-century aesthetics could be construed as a further tribute to Gluck, whose "reform" operas likewise stand on the threshold between two artistic models, between the classical ideal of his youth and the Romantic music drama of which he is often considered a precursor.

\section{Parallel Highways: Accepting Irreconcilable Differences}

17 What makes versification essential to Adams's strategy in Nixon in China is not so much its direct impact on the listener as its ability to lift the libretto above the level of strictly utilitarian writing and endow the opera with a high degree of complexity, over and above what can be achieved by musical means alone. Somewhat paradoxically, considering that he is one of the most popular operatic composers now alive, Adams insists that he is by no means an "opera buff"; he is on record as deploring the low artistic standards of many productions and complaining that most companies' conservative repertoire choices stand in the way of real creativity:

The bar is so low on the theatrical aspect of opera that I just can't bear to go to the opera most of the time, because what happens on stage is so terrible. [...] When you think of the astonishing productions and imaginative things happening in theater these days, and then you look at what passes for opera... [...] And when you look at the season of most of the opera houses, I would say that 50 percent of the operas don't interest me. (Scheinin)

18 In Nixon in China, his first operatic undertaking, everything is done to counteract this tendency; not only is it a deliberately difficult piece that refuses to "fill out the questionnaire," to borrow Sellars's phrase, but it actively tries to reconsider what opera is capable of in the age of mass media, when it needs to struggle for cultural relevance instead of lazily counting on a devoted audience with a high tolerance for 
routine. Verse-the more innovative the better-is an important component of this project: in combination with Adams's rich and original music, it creates a multilayered work that cannot be embraced in its totality from any single perspective, and the resulting impression that there is always more to the opera than meets the eye-or the ear-is precisely what keeps audiences on the edge of their seats. As a manifestation of writing's resistance to the hegemony of music, unconventional versification frustrates the desire for the easy melding of parts into a harmonious whole, insistently raising the issue of form, which Nixon in China repeatedly attempts to dramatize through a series of strategic confrontations and telling metaphors.

One such allusion occurs when Nixon, while thanking his Chinese hosts, describes parallel roads converging towards an infinitely distant point:

We still have differences, God knows,

But let us, in these next five days

Start a long march on new highways,

In different lanes, but parallel

And heading for a single goal. (30)

Nixon's reference to the Long March of the Chinese Communists involves more than simple courtesy, for he appears to imply that America is involved in a similar endeavor: two rival ideologies are at play, but their ultimate purpose is the same, so that it is possible to look for forms of kinship beyond political differences and evoke deep-seated disagreements in terms of harmonic complementarity and meaningful discord. The road metaphor frequently appears in the libretto, invariably associated with the idea of wildly different processes unfolding side by side; it contributes to a complex depiction of human existence where common experiences conjure up dissimilar, and sometimes conflicting, associations while ensuring mutual intelligibility. As he imagines his fellow Americans watching the evening news, Nixon muses:

They watch us now;

The three main networks' colors glow

Livid through drapes onto the lawn. [...]

A car roars past playing loud pop,

Is gone. (9)

His wife Pat likewise exclaims as she draws a vivid word picture of Middle America:

Let lonely drivers on the road

Pull over for a bite to eat,

Let the farmer switch on the light

Over the porch, let passersby

Look in at the large family

Around the table, let them pass. (38)

The "lonely driver" and the "large family" never actually meet; one is on the road and presumably far from home whereas the other enjoys domestic comforts, oblivious to the traffic outside. However, both deal with the same fundamental realities: hunger and the quest for food recall the daily struggle for existence, while the rich meanings and complex emotions associated with the ritual of the evening meal resonate across social and cultural boundaries. The libretto thus depicts a world where most paths seldom cross but where no one is ever completely alone: roads diverge, different choices are made, and strangers barely acknowledge one another, but all pursue a "single goal," sometimes unbeknownst to themselves.

In this context, Nixon's allusion to a car "playing loud pop" appears especially significant, for it is an explicit reminder that the text was written with music in mind: 
the words may appear self-sufficient when encountered on the printed page, but they remain aware of the non-verbal and seemingly incongruous other that constantly accompanies them in performance, even though they can only make passing gestures in its direction. Expertly deployed by Nixon and his wife Pat, who are both depicted by Goodman as prone to impressive flights of rhetoric, words appear to possess unlimited powers; in opera, however, their limitations soon become apparent in the presence of non-verbal modes of expression, a fact of which the text duly takes note but to which it must resign itself in view of music's inassimilable difference. In his setting of Nixon's aria, Adams refuses to take the hint and recreate the sound of a seventies pop song to suggest the passing car, which is imagined but not heard, consigned to the same unreality as the rest of Nixon's vision. True, notable instances of word painting do in fact occur. For instance, the pulse that otherwise runs through the entire aria briefly slackens and stops as Nixon mentions "the Earth's Sea of Tranquillity," conflating the unfamiliar landscape of Communist China with the lunar vistas revealed by the Apollo missions (Goodman 9): suddenly, the restless, pathologically anxious president appears to enjoy an uncharacteristic moment of inner peace (Adams, 1987 97-98). Earlier on, he quotes the title of a well-known jazz standard, Brooks Bowman's "East of the Sun (and West of the Moon)," which the audience may recognize from its many recordings by such prominent artists as Ella Fitzgerald, Sarah Vaughan, and Billie Holiday:

NIXON

The Eastern Hemisphere

Beckoned to us, and we have flown

East of the sun, west of the moon

Across an ocean of distrust

Filled with the bodies of our lost [...]. (9)

Appropriately, these words are accompanied by a jazz ensemble (keyboard, saxophones, and clarinets; 1987 94-95), in a clear nod to the big-band sound that Adams associates with Nixon: "[i]t was the music of my parents, [...] and with its admixture of sentimentality and reminiscence it conveyed to me the ideal of Nixon's imagined Middle America" (2008 141). However, this kind of convergence between libretto and score is the exception, not the rule. Not only does Goodman's text hint at musical opportunities that the composer is unwilling to seize, but his treatment of the vocal line frequently distorts the libretto's elaborate prosody when it does not alter it out of recognition. "Who are our enemies? Who are/Our friends?" Nixon wonders as he begins to suspect that his efforts may be met by "ingratitude," indulging a dangerous fondness for self-exoneration (Goodman 9-10). For once, the enjambment meaningfully inflects the character's delivery as he stumbles on the word "friends," seemingly unable to believe that anyone can be trusted. In the score, Adams does not take the hint; instead, both occurrences of the word "who" are insistently repeated, stressing the rhetorical parallel between the two questions rather than the subtle difference suggested by Goodman (92-93). Earlier on, Nixon is shown forging on in complete disregard of Chou En-lai's polite attempt at an interruption as the Chinese premier tries to introduce a cabinet minister to the visiting head of state:

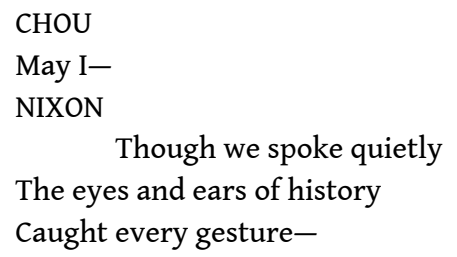






The libretto suggests a subtle opposition between Nixon, who doggedly adheres to the meter despite his interlocutor's timid interventions, and Chou's near inability to complete a line of verse, as he is forced to cram his words into the remaining space. Here, Adams introduces an extraneous word: "And though we spoke quietly" (1987 75). This semantically pointless addition disrupts the iambic meter, so that the line no longer scans properly; its sole purpose is musical as it provides the composer with an opportunity to begin the melodic segment with an anacrusis, giving it a buoyancy that it would otherwise lack. None of these discrepancies between the libretto and its musical setting indicate that Adams reacted to Goodman's suggestions with indifference or casual disregard; on the contrary, the text is handled thoughtfully and discriminatingly, in a manner that demonstrates Adams's awareness of its complexities and his ability to draw inspiration from it without slavishly following it at every turn. Instead, what these examples reveal is the libretto's curious helplessness as it keeps trying to anticipate its musical treatment without ever being sure that its guesses are correct. In its published form, the text of Nixon's aria reads like a complete, coherent soliloquy, whose air of self-sufficiency aptly mirrors the character's arrogance and inability to listen. In its operatic context, the same speech sounds almost tentative, not because the composer's take on Nixon's personality is in any way different from the librettist's, but because it is up to the music to endorse or to reject the libretto's suggestions. For all his bluster, Nixon's words have an air of insecurity about them as it is apparent that the situation is beyond his control, even though his rhetoric is not; like a jetlagged traveler surprised by the time difference, he exists in two different dimensions at once, and the resulting dislocation makes his confident assertions of power sound almost nonsensical:

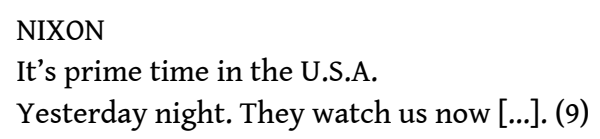

Elsewhere, Goodman's libretto suggests a way of coming to terms with the discord, and potential conflict, between text and music by juxtaposing two different discursive modes, one associated with Western definitions of logos, the other with the oblique, elliptical, intentionally ambiguous and open-ended language of the Chinese characters who constantly borrow from the classics of Confucianism. In Act 2, for instance, two radically different forms of prophetic discourse occur side by side, in a way that highlights both their kinship and their radical incompatibility. While visiting the Forbidden City, Pat Nixon suddenly has a vision of the world to come, where the material and the spiritual will merge so thoroughly that every sensual experience will acquire an almost mystical resonance:

This is prophetic! I foresee

A time will come when luxury

Dissolves into the atmosphere

Like a perfume, and everywhere

Transatlantica, 1 | 2021 
The simple virtues root and branch

And leaf and flower. (37) striking reference to the parable of the Prodigal Son, followed by a mention of Resurrection, confirms that she is attempting to describe, in near-Christian terms, the mystical union of time and eternity: "The sirens wail / As bride and groom kiss through the veil." A few moments later, her Chinese guides make a series of enigmatic comments about the statues recently discovered by archaeologists in the tombs of the Ming emperors:

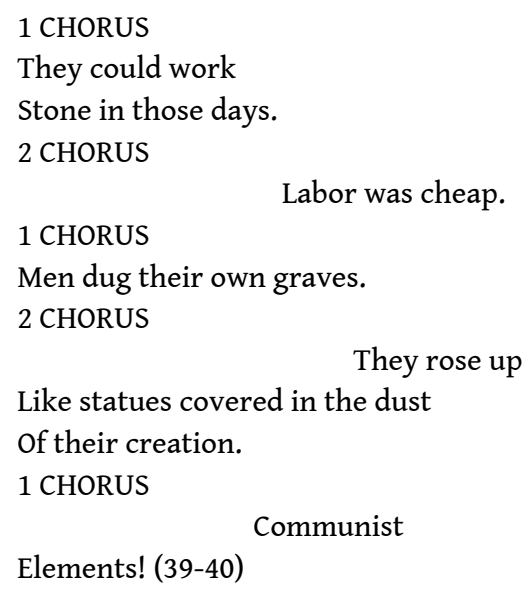

All of a sudden, the tone changes radically; wild flights of rhetoric and intricate grammatical structures are abandoned in favor of a much more economical form of speech which seemingly privileges the literal but gives so much importance to minute details that the listener is tempted to look everywhere for concealed symbolic meanings: "The salt was black. They drank white tea" (40-41). This, in fact, may well be the desired response: as Timothy A. Johnson notes, "white tea" is a Chinese euphemism for plain boiled water drunk during famines (76). The chorus is attempting to warn Mrs. Nixon that all is not as it seems and that the awe-inspiring monuments of imperial China give a false impression of the lives of their builders; likewise, it is implied, she would be wise to suspect that the happy scenes she just witnessed at the Evergreen People's Commune were staged on purpose to disguise the truth about the Maoist regime. Despite the plain syntax, the chorus's comments thus turn out to be as complex as Pat's poetic meditation, but for rather different reasons, as they conceal a message about the government's deceptive measures and guardedly deploy a succession of understatements to warn the American guest that she is being intentionally misled by the authorities. Like Pat, the chorus draws on a repertoire of intertextual references to make its meaning clear, or as clear as possible under the circumstances; but she is obviously unfamiliar with classical Chinese literature, and it is therefore the listener's responsibility to identify the allusions. The workers who built the Ming tombs are described as "[s]wimming through space as fish swim through / The sea. Resting in currents" (40). This formulation sounds reminiscent of the I Ching (hexagram 48, "The Well"): "The town may be changed. / But the well cannot be changed. / It neither increases nor decreases. / They come and go and draw from the well" (185). Could it be a coded reference to the enduring foundations of the social order, which remain in place despite dynastic turmoil and the grand schemes of revolutionary leaders? The question remains unanswered, not just because the chorus is attempting to dodge government surveillance, but also, more fundamentally, because ambiguity is an 
essential feature of the I Ching, which can be used for divination purposes precisely because it never says anything in a completely straightforward manner: the truth of the oracle lies not in the text itself, but in the endlessly new ways people interpret it in the light of their own preoccupations. An unlikely prophet, Mrs. Nixon is not used to this mode of thinking; "I don't daydream and I don't look back," she breezily claims as the curtain rises (34), moments before she is seized by a sudden inspiration to do just that. As Peter Sellars points out,

This [exchange] is the first indication that this isn't just a vacation, and that actually you don't know you are in this country at the moment when it is tearing itself apart; you don't know it, because a giant façade has been put up. [...] Mrs. Nixon, being gracious, is not able to pick up on the note of menace and concern that the women are trying to indicate, because of course they are not allowed to say anything to her. (Daines 14)

Unable to comprehend what she is being told, Pat Nixon takes the arm of her interpreter and leaves-a "friendly gesture," the stage direction points out (41): friendship here stands for the happy acceptance of irreconcilable and potentially unsettling differences, for a warm and loving display of solidarity which makes all explanations unnecessary.

\section{Enjambments as Musical Effects}

To a listener mesmerized by Adams's rich and powerful score, versification is the unseen, imperceptible other whose hidden presence is suspected but whose reality remains elusive; but this does not make it irrelevant, since the entire opera is about the disturbing proximity of the unknown. As Peter Sellars told Matthew Daines,

What the opera finally gets to the point of is that, all night long, you have had this illusion that you understand China-here we are, it's an open book etc.-the second act begins to imply with Pat Nixon that there are certain things that she will never know. (13)

Likewise, Goodman's libretto gestures towards the music that accompanies it, admitting that it "will never know" the truth and that finding out matters less than practicing an ethics of acceptance and neighborly good feeling: "grace" may not have the ability to bridge the gap, but at least it does not attempt to force the relationship between words and music into a predetermined pattern that negates its complexity. However, on a number of occasions, this enduring rift does not prevent versification from assisting the composer in his quest for striking musical effects. In an opera, prosody serves a key musical purpose, and any literary device that creates distinctive verbal patterns with strong rhythmic properties is bound to attract the musician's, and therefore the listener's, attention. This is especially true of unusual line breaks and creative enjambments, which loosen up the meter and allow for great flexibility while preserving a sense of regularity.

Adams's strong preference for setting a verse libretto makes sense considering the rest of his output, and so does his willingness to work with a librettist with a keen ear for the endless variations that can arise even within the strictest metrical framework. He appears strongly attracted to traditional versification; Harmonium (1980), his first vocal work, sets poems by John Donne and Emily Dickinson, and verse largely predominates in most of his operas and oratorios. What draws him to this mode of writing seems to be what the Latin language calls versus, the sense of regular repetition and reprise; this 
may also explain his apparent fondness for the rhetoric of enumeration, as evidenced by his cantata On the Transmigration of Souls (2002) whose libretto lists at length the names of people killed in the 9/11 attack on the World Trade Center. However, the fact is that this tendency to repetition, combined with a taste for large choral and orchestral ensembles, can lend some of his music an air of impressive, almost crushing monumentality. An example occurs at the beginning of Nixon in China, when the opening homorhythmic chorus chants a poetic text composed of self-contained, gnomic-sounding lines, as if to suggest the irresistible march of history:

The people are the heroes now

Behemoth pulls the peasant's plow

When we look up, the fields are white

With harvest in the morning light

And mountain ranges one by one

Rise red beneath the harvest moon (6)

This chorus exemplifies what Alexander Sanchez-Behar considers a typical feature of Adams's music from the 1980s, namely an interest in translational symmetry, which he defines as "the periodic repetition of an object that preserves its full identity in shape and proportion" (55). As the composer himself pointed out some fifteen years later in a discussion of Fearful Symmetries (1988): "Rather than try to deconstruct the obviousness of these [...] structures, I did the opposite: I amplified their predictability and in so doing ended up composing an insistent pulse-driven juggernaut of a piece" (2008 149-150). While not intended as such, this remark is an accurate description of the opening chorus from Nixon in China: the lines "The people are the heroes now / Behemoth pulls the peasant's plow" are repeated no less than eight times with minimal variations, after which a loudly pulsing bass line introduces the orchestral crescendo that both accompanies and depicts the majestic landing of the presidential plane.

As they multiply in subsequent scenes, unusual line breaks interfere with this seemingly irresistible progression; they do not suspend the basic metrical pattern but make the text's prosody more unpredictable, allowing the composer to identify units of meaning whose length is not predetermined by metrical constraints. This can occur in one of two ways. In some cases, enjambments isolate short groups of words chosen for their prosodic properties; thus, in the chorus that follows Pat Nixon's aria, the words "Communist/Elements!" (Goodman 40) acquire a special resonance, not so much because of their meaning as because the two dactyls stand out against the regular 12/8 pattern simultaneously unfolding in the orchestra, and because their subtly differentiated treatment disturbs what could have been a simple case of translational symmetry-the former ("Communist") is sung on a dotted rhythm, whereas the latter ("elements") is set as a group of three eighth notes (Adams, 1987 470).

In other instances, enjambments allow lengthy sentences to disregard normal line divisions and thereby create complex textual rhythms for which a strictly metrical analysis does not account on its own, again pointing to unexpected musical possibilities. Thus, when he finally meets Nixon, Mao observes that

[t]he people are determined to

Divide the land to make it whole.

Piecing the broken Golden Bowl

The world to come has come, is theirs.

We cried "Long live the ancestors!"

Once, it's "Long live the living!" now. (20) 
Syntactically speaking, the last two lines consist of two clauses built on the same pattern, with rigorously parallel meanings (what we cried "once" vs. what we cry "now"). The line break disrupts the symmetry, as the adverb "once" is visually separated from the rest of the clause to which it logically belongs. This creates an imbalance since the first of the two lines misleadingly appears complete at first-the word "once" is semantically relevant but grammatically unnecessary, and the reader has to "piece" the first part of the sentence together, much as if it were the "broken Golden Bowl." The apparent disturbance is made up for in the second line, which begins and ends with two semantically contrasting adverbs enclosing the central statement: "it's 'Long live the living!" While this is grammatically odd, the echo between the first and last words of the final line creates a peculiarly satisfying impression of closure as the text vividly emphasizes the difference between past and present practices, between the age-old ritual of ancestor worship, which has been abandoned in Maoist China, and the current preoccupation with improving the lot of the formerly disenfranchised masses. All in all, the slight discrepancy between the rhetorical pattern (the two identically structured clauses) and the metrical pattern creates an effect that can be likened to a dissonance followed by its resolution: order is disrupted, then reestablished, mirroring Mao's meaning as he insists that the previously "divided" land will once again be made "whole." Significantly, the entire passage pivots on one ambiguous metaphor, the "broken Golden Bowl." There is ample justification for its appearance in this context as it is borrowed from one of Mao's own poems, known in English as "The Warlords Clash" (1929); in it, the Communist leader celebrates land reform and the long awaited passing of the feudal order, which persisted in the decades that followed the fall of the Qing dynasty as the country was divided between regional factions: "We have reclaimed part of the golden bowl / And land is being shared out with a will" (Mao 10). The American visitors are presumably unfamiliar with this literary reference, but the phrase "the golden bowl" carries other associations in an Anglophone setting, as it recalls Henry James's eponymous novel (1904) as well as the passage from Ecclesiastes from which its title is borrowed: "[whenever] the silver cord be loosed, or the golden bowl be broken, or the pitcher be broken at the fountain, or the wheel broken at the cistern. Then shall the dust return to the earth as it was" (Ecclesiastes 12: 6-7). By a lucky coincidence, the same image has a strong symbolic value in both cultures, where it carries opposite meanings: in Ecclesiastes, the golden bowl represents the inevitability of death, whereas Mao's poem invokes it to suggest a near-miraculous recovery after a period of prolonged instability. As a result, this near misunderstanding does not preclude an intuitive rapprochement, as befits the general mood of the opera: English speakers are able to perceive the emotional impact of Mao's gnomic statement even if the precise reference remains obscure; the 1929 poem may not be widely known outside China, but the sense of triumph is palpable as the idea of "piecing the broken Golden Bowl" comes across as a powerful promise of renewal.

In the score, Adams makes creative use of the complex patterns thus created. The opening lines of the passage, "The people are determined to/Divide the land and make it whole. Piecing the broken Golden Bowl," are sung to an almost static vocal line that does not stray beyond a minor third. The words "The world to come has come, is theirs" are sung three times recto tono; then, as Johnson notes (176), the melody becomes more ambitious, infusing the last two lines with a strong lyricism. It is heard three times as Mao describes the onetime cult of the ancestors, then taken up again, in 
slightly altered form, as he moves on to an evocation of the present: the word "now" is set a third higher than the word "once," inviting the listener to perceive the similar functions they play while recognizing that a stronger emphasis falls on the present moment. At first, it is tempting to consider that this sudden illumination marks an ecstatic pause, as the Chinese leader contemplates the "world to come"; the sense that an epiphany has been achieved is fully in keeping with the eschatological significance that the Golden Bowl metaphor carries to an American ear. However, the change to the melody, accompanied by a harmonic switch from $G$ to $B$ minor, suggests that time continues to pass, albeit almost imperceptibly: attention thus shifts to the word "now," which designates a nunc stans providentially immune to alteration and decline even as it marks a stage in an ongoing process, humankind's long march on the road to universal peace (Adams, 1987 187-195).

In both cases, the creative use of line breaks provides the composer with an opportunity to loosen up otherwise rigorous prosodic structures. Like peculiar score markings, the enjambments serve as graphic tools that notate significant musical effects. As such, they have a discernible impact on the listener's experience, even if the audience do not quite understand how: the fact that the enjambments are not recognized for what they are does not make them irrelevant to the ear, but simply means that they perform the same function as a changing time signature, which does not have to be understood in order to be felt. However, Nixon in China also provides at least one striking example where an exceptionally significant line break forces the melodic line into a shape that audibly betrays its presence, thus giving the letter of the text precedence at the expense of the music. It occurs near the close of Act 2 when Chiang Ch'ing, otherwise known as Madame Mao, launches into a furious aria where she vents her frustration and anger.

I am the wife of Mao Tse-tung

Who raised the weak above the strong

When I appear the people hang

Upon my words, and for his sake

Whose wreaths are heavy round my neck

I speak according to the book. (52)

In the libretto, this is a rare instance of a semantically significant line break, as the enjambment belies the text's explicit meaning to suggest Chiang Ch'ing's active participation in the crimes committed during the Cultural Revolution (Johnson 142). Here, the composer reverts to the approach he adopted in the opening chorus and writes a melody whose prosody closely follows the basic metrical pattern, marking a pause at the end of each line. As a result, the singer briefly stops after the word "hang," giving the impression that the sentence is complete; the same words are repeated to a different accompaniment and, at long last, the voice moves on to the next line, making the addition "upon my words" sound like an unconvincing afterthought. On the one hand, Adams's music thus emphasizes the character's overweening pride, conferring on her aria a monumentality of utterance that befits the flattering account she gives of herself: by adopting a melodic structure that recalls the soldiers' chorus, it appears to confirm her belief that she speaks for the Chinese people, as one expects of a great revolutionary leader. On the other hand, the audible enjambment lampoons her delusions of grandeur: the figure she cuts is that of a monster, and an incompetent one at that since she cannot control her own delivery, let alone the actions of her subordinates. While the point is clearly-and, in an opera which tends to avoid any hint 
of partisanship, unusually-satirical, there is once again a meta-operatic dimension to all this since the audience willingly "hang upon" the character's words, mesmerized by the virtuoso vocal display in which the singer indulges. Violence is everywhere in this scene, at once proudly displayed, cleverly deflated, and savagely mocked; here, opera is exposed as a theater of cruelty where the audience participates in a form of collective victimization at the expense of the soprano who must meet the demands of a difficult showpiece aria while pretending to share Chiang Ch'ing's callous indifference to the opinions of others. However, her outburst also demonstrates that violence-on stage if not, alas, in the real world-is held in check by the thoughtful collaboration between words and music: in the end, Chiang Ch'ing "speak[s] according to the book"-Mao's Little Red Book, no doubt, but also Alice Goodman's libretto, which puts incriminating words in her mouth without her knowledge, thus ultimately serving the cause of peace. As Nixon reassuringly points out to his wife when she reacts in horror to a violent scene in the ballet performed for them by a troupe of Chinese dancers, "It's just a play. / [The victim]'ll get up afterwards, you'll see" (45). Opera, like war, is dislocated; but there the similarity ends: a surprising line break is always preferable to a real break, and the Golden Bowl, for all its cracks, is invariably pieced together in the end.

\section{BIBLIOGRAPHY}

The I Ching or Book of Changes. 1950. Translated from the Chinese by Richard Wilhelm and Cary F. Baynes. Princeton: Princeton University Press, 1967.

ADAMS, John. Official Composer Website. www.earbox.com . Accessed 19 February 2021.

ADAMS, John. Hallelujah Junction: Composing an American Life. New York: Farrar, Straus \& Giroux, 2008.

ADAMS, John. Nixon in China. Boosey \& Hawkes/Hendon Music, 1987.

DAINES, Matthew. “Nixon in China: An Interview with Peter Sellars.” Tempo, no. 197, July 1996, p. 12-19.

FEND, Michael. "Romantic Empowerment at the Paris Opera in the 1770s and 1780s." Music \& Letters, vol. 94, no. 2, May 2013, p. 263-294.

GOODMAN, Alice, Nixon in China. 1991. History is Our Mother: Three Libretti. New York: New York Review Books, 2017, p. 1-69.

JOHNSON, Timothy A. John Adams's Nixon in China: Musical Analysis, Historical and Political Perspectives. London: Ashgate, 2011.

KAIZEN, William R. “Richard Hamilton's Tabular Image.” October, no. 94, 2000, p. 113-128.

MAO ZEDONG. "The Warlords Clash.” Poems. Anonymous translator. Open Source Socialist Publishing, 2008. socialistpublishing.files.wordpress.com/2010/05/maopoems-newsetting.pdf, 10. Accessed 19 February 2021.

MARVELL, Andrew. The Complete Poems. Harmondsworth: Penguin Books, 1972. 
MAY, Thomas. “She Gave Words to Opera's Nixon.” The New York Times, 22 August 2017. www.nytimes.com/2017/08/22/arts/music/nixon-china-john-adams-alice-goodman-petersellars.html. Accessed 19 February 2021.

PERLOFF, Marjorie. Twenty-First Century Modernism: The "New" Poetics. Oxford: Blackwell, 2002.

RAHIM, Sameer. “Alice Goodman on Writing Political Operas-and Her Late Husband Geoffrey Hill." Prospect, 17 August 2017. www.prospectmagazine.co.uk/magazine/alice-goodman-onwriting-political-operas-and-her-late-husband-geoffrey-hill. Accessed 19 February 2021.

ROSEN, Charles. The Classical Style: Haydn, Mozart, Beethoven. 1971. London: Faber \& Faber, 1997.

SANCHEZ-BEHAR, Alexander. "Symmetry in the Music of John Adams." Tempo, vol. 68, no. 268, April 2014, p. 46-60.

SCHEININ, Richard. "John Adams on First-and Perhaps Favorite-Opera, Nixon in China." The Mercury News, 6 July 2012. www.mercurynews.com/ci_20805969/john-adams-his-first-andperhaps-favorite-opera . Accessed 19 February 2021.

SÖRING, Jürgen. "Gesamtkunstwerk.” Reallexikon der deutschen Literaturwissenschaft. Ed. Klaus Weimar. Vol. 1. Berlin: De Gruyter, 1997, p. 710-712.

STEINBERG, Michael. "Nixon in China." 1988. Liner notes for the Nonesuch recording. The John Adams Reader: Essential Writings on an American Composer. Ed. Thomas May. Pompton Plains: Amadeus Press, 2006, p. 110-119.

TARLING, Nicholas. Orientalism and the Operatic World. Lanham: Rowman \& Littlefield, 2015.

WILLIAMS, William Carlos. "The Red Wheelbarrow." 1923. The Collected Poems. Vol. 1 (1909-1939). Ed. A. W. Litz and C. MacGowan. New York: New Directions, 1986.

\section{NOTES}

1. Throughout this article, the Pinyin system will be used to transcribe Chinese names when they refer to actual historical figures; this will distinguish them from the opera's semi-fictional characters, as the libretto uses the Wade-Giles romanization system.

2. The Death of Klinghoffer recreates a particularly painful event, the 1985 hijacking of the Italian cruise liner Achille Lauro by a group of Palestinian activists and the subsequent murder of Leon Klinghoffer, a Jewish American tourist. Ever since its 1991 premiere, the opera has been controversial in the United States, where many people view it as antisemitic; all its major American revivals have been greeted by increasingly acrimonious protests, most recently in 2014 when it was produced at the Metropolitan Opera (Michele Bachmann and Rudy Giuliani supported the demonstrators, while Ruth Bader Ginsburg sided with the composer and librettist). Despite the controversy, Adams was able to continue writing for the stage; since 1991, he has composed several more operas, two staged oratorios, and a musical, most of which have been warmly received. Unlike him, Goodman found herself unable to get commissioned; eventually, she chose to abandon her career as a librettist (May).

3. Interestingly, a Steinian inspiration is also apparent in some of the whimsical titles that John Adams chooses for his instrumental compositions; thus, he points out that the title of Gnarly Buttons, a 1996 piece for solo clarinet and chamber orchestra, alludes to her 1914 poetry collection Tender Buttons (Official Composer Website). 


\section{ABSTRACTS}

The purpose of this article is to examine the role of line breaks in the libretto Alice Goodman wrote for Nixon in China (1987), her first collaboration with composer John Adams. In the opera, enjambments function first and foremost as literary devices; as such, they emphasize the text's autonomy and its independence from its musical setting. On a meta-operatic level, the resulting discrepancy between words and music draws attention to the various modes of dislocation at play in an opera whose plot hinges on the acceptance of irreconcilable differences. Finally, the article considers the musical function of line breaks: they loosen up the meter and create complex patterns, which the composer uses for his own purposes.

Le présent article examine la place des enjambements dans Nixon in China (1987), le premier opéra écrit par Alice Goodman en collaboration avec le compositeur John Adams. Dans cet ouvrage, les enjambements ont pour fonction première d'attirer l'attention sur l'autonomie du texte, qui se déploie selon une tout autre logique que la partition ; à ce titre, leur rôle est d'abord littéraire. En termes méta-opératiques, ce décalage entre texte et musique attire l'attention sur les diverses formes de dislocation à l'œuvre dans un opéra dont l'intrigue repose sur l'acceptation bienveillante de différences irréconciliables. Enfin, l'article étudie la fonction musicale des enjambements : ils permettent au discours d'échapper provisoirement à la tutelle du mètre et donnent naissance à des motifs prosodiques complexes que le compositeur utilise à ses propres fins.

\section{INDEX}

Keywords: Alice Goodman, John Adams, Nixon in China, opera, enjambment

Mots-clés: Alice Goodman, John Adams, Nixon in China, opéra, enjambement

\section{AUTHOR}

\section{MATHIEU DUPLAY}

Université de Paris - LARCA UMR CNRS 8255 